Check for updates

Cite this: RSC Adv., 2017, 7, 30855

Received 10th January 2017

Accepted 10th April 2017

DOI: 10.1039/c7ra00362e

rsc.li/rsc-advances

\section{Protective effects of lipid extract from brains of silver carp against oxidative damage in HEK-293 cells}

\begin{abstract}
Caixia Wang, (D) ab Wenshui Xia, ${ }^{\text {tb }}$ Qixing Jiang, ${ }^{\mathrm{b}}$ Yanshun $\mathrm{Xu}{ }^{\mathrm{b}}$ and Peipei $\mathrm{Yu}^{\mathrm{b}}$
Previous studies verified the protective effects of fish lipids against diseases caused by oxidative damage. Fish brains are rich in lipids. However, the actions and mechanisms of fish brain lipids on potent antioxidant activities remain unclear. In this study, total lipids (TLS) extracted from silver-carp brain were separated into neutral lipids (NLs) and polar lipids (PLs), and the protective roles of lipid fractions (LFs) against $\mathrm{H}_{2} \mathrm{O}_{2}$-induced oxidative damage were examined in a human embryonic kidney 293 (HEK-293) cell line. LFs effectively resisted $\mathrm{H}_{2} \mathrm{O}_{2}$-induced oxidative injury in $\mathrm{HEK}-293$ cells by reducing cellular reactive oxygen species levels, protecting cellular antioxidant enzyme systems, inhibiting cell apoptosis and necrosis, and diminishing loss of mitochondrial-membrane potential. Among the TLs, PLs surpassed NLs in conferring antioxidant activities. The present study may help to explain the protective role of fish lipids against diseases caused by oxidative damage and promote fish-brain-derived lipids as potential preventive and therapeutic agents for human health.
\end{abstract}

\section{Introduction}

Epidemiological studies suggested that fish-oil consumption is associated with reduced cardiovascular disease in humans. ${ }^{1}$ This notion is supported by clinical trials where fish-oil supplementation reduced the risk of cardiovascular disease. ${ }^{2,3}$ Oxidative damage is believed to contribute to pathogenesis of cardiovascular events. ${ }^{4}$ Polyunsaturated fatty acids (PUFAs), especially $\omega-3$ fatty acids (FAs), are proven antioxidants in vitro and in vivo. ${ }^{5,6}$ Thus, protective functions of fish oil, which is rich in PUFAs, against cardiovascular disease may be partly ascribed to its antioxidative effects. Although studies have been conducted to explain the role of fish lipids against oxidation, involved mechanisms require further research.

In Chinese tradition, fish brain is regarded as physically and neurologically nutritious and beneficial to humans. This food is popular in China and is currently of industrial interest. Previous studies showed that fish brain is rich in lipids and contain large amounts of PUFAs, especially $\omega-3$ FAs. ${ }^{78}$ However, fish brain has been seldom exploited for health issues. Our previous study demonstrated that the brain of silver carp (Hypophthalmichthys molitrix), a majorly cultured fresh water fish species in China, contains abundant lipids (20.53\%) and physiologically and neurologically beneficial FAs. These FAs mainly include $\alpha$ linolenic acid (67.66 $\mathrm{mg} \mathrm{g}^{-1}$ brain lipids), arachidonic acid (24.31 $\mathrm{mg} \mathrm{g}^{-1}$ brain lipids), eicosapentaenoic acid (EPA,

${ }^{a}$ College of Food Science, Sichuan Agricultural University, Yaan 625014, China

${ }^{b}$ School of Food Science and Technology, Jiangnan University, Wuxi 214122, China. E-mail: xiaws@jiangnan.edu.cn; Fax: +86 510 85329057; Tel: +86 51085919121
$51.74 \mathrm{mg} \mathrm{g}^{-1}$ brain lipids) and docosahexaenoic acid (DHA, $69.52 \mathrm{mg} \mathrm{g}^{-1}$ brain lipids). ${ }^{9,10}$ We also observed that lipids from silver carp exhibit good biological properties, such as antiplatelet-activating factor and antibacterial and anticancer activities. ${ }^{11,12}$ Moreover, lipids from silver-carp brain exert a strong scavenging effect on 2,2-diphenyl-1-picrylhydrazyl radical, ${ }^{12}$ which initially demonstrated the antioxidative potential of silver-carp brain lipids. However, further studies are still required.

In this study, human embryonic kidney 293 (HEK-293) cells were used. $\mathrm{H}_{2} \mathrm{O}_{2}$, as a major contributor to oxidative stress, was served to treat HEK-293 cells and to obtain in vitro oxidativedamaged mimic mode for investigating whether lipids extracted from silver-carp brains have antioxidant effects. Furthermore, to clarify effect mechanisms, total lipids (TLs) from silver carp brain were divided into polar lipids (PLs) and neutral lipids (NLs) for assessment. Tests and comparisons were conducted to display protective effects of lipid fractions (LFs) on viability of HEK-293 cells against $\mathrm{H}_{2} \mathrm{O}_{2}$-induced oxidative damage. Moreover, changes in morphology, reactive oxygen species (ROS), antioxidant enzyme, DNA content, apoptosis, and mitochondrialmembrane potential $\left(\Delta \Psi_{\mathrm{m}}\right)$ were assessed to further elucidate the activities of LFs in $\mathrm{H}_{2} \mathrm{O}_{2}$-oxidative damaged HEK-293 cells.

We believe that understanding the antioxidant mechanisms of LFs derived from silver-carp brain may help gain insight into the role of fish lipids in prevention/therapy of diseases (e.g., cardiovascular disease) caused by oxidative damage. Such knowledge may also potentially aid in improving outcomes of treating such diseases when LFs are used with conventional therapeutic strategies. Furthermore, this study may shed light 
on prospective commercial applications and industrial exploitations of silver-carp brain lipids for the benefit of human health.

\section{Materials and methods}

\subsection{Materials}

Live silver carps (1.5-2 kg, $n \geq 100)$ were purchased from a local market (Wuxi, Jiangsu Province) and decapitated in the laboratory. Brains were removed, collected, and homogenized (T10 basic Ultra-Turrax homogenizer, IKA, Germany). Prepared brain samples were kept at $-70{ }^{\circ} \mathrm{C}$ before lipid extraction. Animal Ethics Committee of Jiangnan University, China approved this study. All procedures were performed according to regulations and guidelines established by this committee.

Lipids were extracted using a method described by Folch et al. ${ }^{13}$ Briefly, $5 \mathrm{~g}$ of the sample was homogenized with $100 \mathrm{~mL}$ of the solvent system of chloroform/methanol $(1: 2 \mathrm{v} / \mathrm{v})$. The mixture was agitated for $15 \mathrm{~min}$ in an orbital shaker (KS130, IKA, Germany) at room temperature. After removing solid residues through filtration, the solvent was washed with 0.2 volume of $0.9 \% \mathrm{NaCl}$. The mixture was shaken vigorously in a separation funnel to separate the two phases. The lower phase containing TLs was collected, evaporated under reduced pressure, and dried under $\mathrm{N}_{2}$ blow.

TLs were separated into NLs and PLs via countercurrent distribution. ${ }^{\mathbf{1 4}}$ Petroleum ether and $87 \%$ ethanol were preequilibrated in a separatory funnel. The lower phase containing equilibrated $87 \%$ ethanol and the upper phase containing equilibrated petroleum ether were collected separately. Briefly, $10 \mathrm{~g}$ of the dried TL was dissolved in $45 \mathrm{~mL}$ of pre-equilibrated petroleum ether. The mixture was added with $15 \mathrm{~mL}$ of preequilibrated $87 \%$ ethanol and stirred. The lower phase, which is the ethanol phase, was collected and transferred to a second test tube containing $45 \mathrm{~mL}$ of pre-equilibrated petroleum ether and stirred again. Ethanolic phase was transferred to a third empty test tube. The procedure was repeated eight times. Finally, the ethanolic phase $(8 \times 15 \mathrm{~mL})$ containing PLs and the phase of petroleum ether $(2 \times 45 \mathrm{~mL})$ containing NLs were evaporated in vacuum and blown under $\mathrm{N}_{2}$ to dryness.

\subsection{Cell culture and treatment}

HEK-293 cells were obtained from the cell bank of the Chinese Academy of Science. HEK-293 cells were cultured in highglucose Dulbecco's modified Eagle's medium (HG-DMEM) supplemented with $10 \%$ fetal bovine serum, 100 units per $\mathrm{mL}$

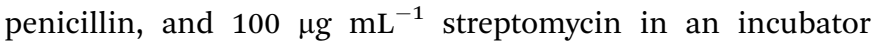
aerated with $5 \% \mathrm{CO}_{2}$ at $37{ }^{\circ} \mathrm{C}$. LFs were freshly dissolved in ethanol and diluted with HG-DMEM [final concentration of ethanol was $1 \%(\mathrm{v} / \mathrm{v})] \cdot \mathrm{H}_{2} \mathrm{O}_{2}$ was used to produce oxidative stress. For the model group, HEK-293 cells were treated with $1 \mathrm{mmol} \mathrm{L}{ }^{-1} \mathrm{H}_{2} \mathrm{O}_{2}$ for $2 \mathrm{~h}$. For treatment groups, cells were pretreated with $1 \mathrm{mg} \mathrm{mL}^{-1} \mathrm{LFs}$ for $1 \mathrm{~h}$ prior to exposure to $\mathrm{H}_{2} \mathrm{O}_{2}$ for $2 \mathrm{~h}$. For the control group, experiment was performed in the presence of $1 \%(\mathrm{v} / \mathrm{v})$ ethanol.

\subsection{Cell viability assay}

3-(4,5-Dimethyl-2-thiazolyl)-2,5-diphenyl-2 $H$-tetrazolium bromide (MTT) assay was used to determine cell viability. Briefly, HEK293 cells $\left(3.0 \times 10^{4}\right.$ cells per well $)$ were seeded in 96-well plates, grown until confluency $(12 \mathrm{~h})$, and then treated with LFs and $\mathrm{H}_{2} \mathrm{O}_{2}$. After replacement with fresh medium, $20 \mu \mathrm{L}$ MTT ( $5 \mathrm{mg} \mathrm{mL}^{-1}$, dissolved in PBS) was added, and cells were incubated for $4 \mathrm{~h}$ at $37^{\circ} \mathrm{C}$ in a humidified incubator with $5 \%$ $\mathrm{CO}_{2}$. Medium was carefully removed, and $150 \mu \mathrm{L}$ of dimethyl sulfoxide was added to each well. The plate was shaken for $10 \mathrm{~min}$, and absorbance was measured on a SH-1000 microplate reader at $570 \mathrm{~nm}$ wavelength. Results were expressed as percentage of viability $(\%)=[(\mathrm{OD}$ value of treated cells/OD value of control cells)], where OD means optical density.

\subsection{Observation of morphological changes}

HEK-293 cells $\left(9.0 \times 10^{5}\right.$ cells per well $)$ were seeded in six-well plates, grown until confluency $(12 \mathrm{~h})$, and treated with LFs and $\mathrm{H}_{2} \mathrm{O}_{2}$. Cells were examined under an inverted-phase contrast microscope (BX41, Olympus, Japan) and then with a fluorescence microscope (BX41, Olympus, Japan) after staining with Hoechst 33258 dye.

\subsection{Intracellular ROS detection}

HEK-293 cells $\left(5.0 \times 10^{3}\right.$ cells per well) were seeded in clearbottom black-walled 96-well plates and grown until confluency. Then, cells were incubated with $2^{\prime}, 7^{\prime}$-dichlorofluorescin diacetate probe in the dark for $20 \mathrm{~min}$ at $37^{\circ} \mathrm{C}$ and washed twice with PBS. Afterward, cells were treated with LFs and $\mathrm{H}_{2} \mathrm{O}_{2}$. Fluorescence intensity of cells was measured using a SpectraMax M5 microplate reader at 488 (excitation) and $525 \mathrm{~nm}$ (emission) wavelengths.

2.6 Measurement of malondialdehyde level and superoxide dismutase, glutathione peroxidase, and catalase activities

Malondialdehyde (MDA) level, and superoxide dismutase (SOD), glutathione peroxidase (GSH-Px), and catalase (CAT) activities were evaluated using their corresponding assay kits (Beyotime, Jiangsu, China). All procedures were conducted in compliance with the manufacturer's instructions. Colorimetric method was used, and the detection wavelengths for MDA, SOD, GSH-Px, and CAT were set to 532, 450, 340, and $520 \mathrm{~nm}$, respectively.

\subsection{Cell-cycle analysis and sub-G1 DNA content assay}

HEK-293 cells were harvested after treatment, washed with icecold PBS, and then fixed in ice-cold $70 \%(\mathrm{v} / \mathrm{v})$ ethanol at $4{ }^{\circ} \mathrm{C}$ for $24 \mathrm{~h}$. Afterward, cells were washed with ice-cold PBS and stained with propidium iodide (PI). After incubating stained cells were in the dark at $37{ }^{\circ} \mathrm{C}$ for $30 \mathrm{~min}$, cell cycle was then analyzed using a flow cytometer (FACSCalibur, Becton Dickinson, USA). The percentage of apoptotic cells with hypodiploid were determined by quantifying the sub-G1 peak. 


\subsection{Cell apoptosis analysis}

An annexin V-fluorescein isothiocyanate (V-FITC) Apoptosis Detection Kit (Beyotime, Jiangsu, China) was used. Briefly, HEK293 cells were trypsinized, harvested, and washed with PBS after treatment. Afterward, the cells were suspended in binding buffer and incubated with annexin V-FITC and PI in the dark at room temperature for $10 \mathrm{~min}$. Cells were analyzed on a flow cytometer and stained with annexin V-FITC, while remaining impermeable to $\mathrm{PI}\left(\mathrm{AV}^{+} / \mathrm{PI}^{-}\right)$, were regarded as early apoptotic cells. This method also distinguished cells undergoing advanced apoptotic and necrosis $\left(\mathrm{AV}^{+} / \mathrm{PI}^{+}\right)$.

\section{$2.9 \Delta \Psi_{\mathrm{m}}$ assay}

A $\Delta \Psi_{\mathrm{m}}$ Detection Kit (Beyotime, Jiangsu, China) was used. Treated HEK-293 cells were harvested and incubated in the dark with JC-1 (a dual-emission potential-sensitive probe) at $37^{\circ} \mathrm{C}$ for $20 \mathrm{~min}$. Cells were then washed twice with JC-1 staining buffer and re-suspended with JC-1 staining buffer to analyze changes in $\Delta \Psi_{\mathrm{m}}$ by a flow cytometer.

\subsection{Statistics}

The data obtained in the present study were expressed as means of three replicated determinations \pm standard deviation (SD). Group means were compared using ANOVA and Duncan's tests on SPSS (version 18.0), and $p<0.05$ was regarded as significant.

\section{Results and discussion}

\subsection{Effects of LFs on cell viability of $\mathrm{H}_{2} \mathrm{O}_{2}$-treated HEK-293 cells}

$\mathrm{H}_{2} \mathrm{O}_{2}$, as a major ROS, elevated oxidative stress and caused apoptosis or necrosis of HEK-293 cells. $^{15}$ In our previous experiments, cell viability was significantly decreased in timeand dose-dependent manners upon treatment with $\mathrm{H}_{2} \mathrm{O}_{2}$. This result suggests that HEK-293 cells were seriously injured by $\mathrm{H}_{2} \mathrm{O}_{2}$. The $\mathrm{IC}_{50}$ of $\mathrm{H}_{2} \mathrm{O}_{2}$ was $0.94 \pm 0.03 \mathrm{mmol} \mathrm{L}^{-1}$ when cells were treated for $2 \mathrm{~h}$. Therefore, $1 \mathrm{mmol} \mathrm{L}{ }^{-1} \mathrm{H}_{2} \mathrm{O}_{2}$ was used to establish an oxidative stress model for HEK-293 cells. Moreover, cytotoxic or proliferative effect was not observed when normal HEK-293 cells were incubated with LFs for $12 \mathrm{~h}$. Cell viability of the model group decreased by half compared with that of the control group (Fig. 1). However, decrease in cell viability was significantly alleviated when LFs were treated prior to $\mathrm{H}_{2} \mathrm{O}_{2}$ exposure. This aspect indicated the protective effects of LFs against $\mathrm{H}_{2} \mathrm{O}_{2}$-induced injury. The effects of muscle lipids (TLM) on cell viability of $\mathrm{H}_{2} \mathrm{O}_{2}$-treated HEK-293 cells were also studied to compare the antioxidant potency of lipids extracted from different parts. TLM showed positive effects against $\mathrm{H}_{2} \mathrm{O}_{2}$ induced damage; however, TLM exerted weaker protecting effects than that TLs extracted from the brain. Cell viabilities of NLs, TLs, and PLs were 63.78\%, 70.12\%, and 79.08\%, respectively, suggesting that PLs protect HEK-293 cells against $\mathrm{H}_{2} \mathrm{O}_{2}$ induced oxidative damage more potently than NLs. As mixture of PLs and NLs, protective effect of TLs was superior to NLs but inferior to that of PLs.

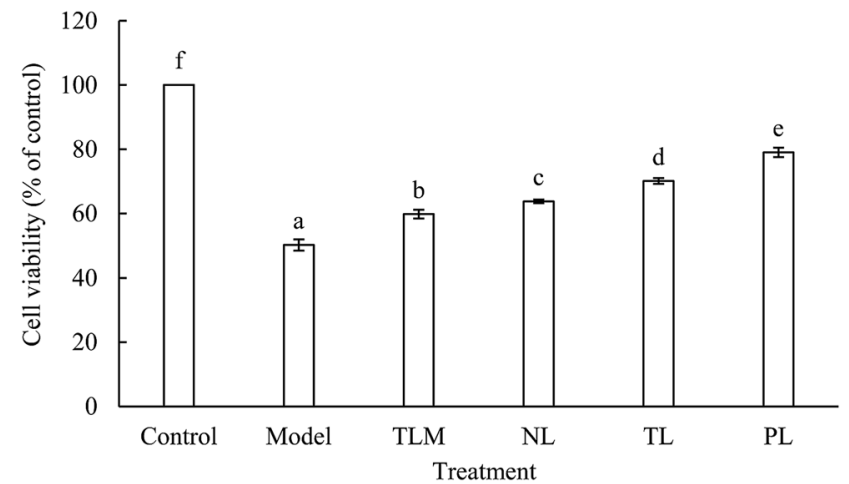

Fig. 1 Effects of silver-carp lipids on cell viability in $\mathrm{H}_{2} \mathrm{O}_{2}$-injured $\mathrm{HEK}$ 293 cells. The model group was incubated with $1 \mathrm{mM} \mathrm{H}_{2} \mathrm{O}_{2}$ for $2 \mathrm{~h}$. Then, treatment groups were incubated with $1 \mathrm{mg} \mathrm{mL}^{-1}$ lipid fractions for $1 \mathrm{~h}$ prior to $\mathrm{H}_{2} \mathrm{O}_{2}$ addition. Results are reported as means $\pm \mathrm{SD}(n=$ 3). The numbers followed by different letters are significantly different at $p<0.05$ on the basis of the Duncan test. TLM-total lipids from muscle, NL-neutral lipids from brain, TL-total lipids from brain, PLpolar lipids from brain.

Oxidative stress is a critical damage route for various psychological disorders; fish oil, which is rich in $\omega-3$ FAs, induces antioxidant effects in the human body. ${ }^{16}$ Liu et al. pretreated mouse neural progenitor cells (NPCs) with DHA and subjected them to oxidative injury induced by $\mathrm{H}_{2} \mathrm{O}_{2}$ incubation. Results showed that DHA pre-treatment increased cell viability and indicated that application of $\omega-3$ PUFAs significantly protected NPCs against $\mathrm{H}_{2} \mathrm{O}_{2}$-induced oxidative injury. ${ }^{17}$ In this study, we demonstrate that pre-incubation with LFs prior to $\mathrm{H}_{2} \mathrm{O}_{2}$ exposure increases HEK-293 cell viability.

Our previous studies showed that PLs account for $22.73 \%$ of the TLs in the silver carp brain and that the total $\omega-3$ PUFAs in PLs (27.64\%) are apparently higher than that in NLs (18.73\%). ${ }^{9}$ Among the biologically active lipids, the phospholipids in PLs, which are more abundant in long-chain PUFAs due to their functional role, are nutritionally and functionally unique. ${ }^{18}$ The phospholipids were found to account for $48.17 \%$ of PLs. ${ }^{9}$ The abundant phospholipid content in PLs and the different FA profiles may be responsible for the strong protective effect of PLs.

\subsection{Effects of LFs on the morphology of $\mathrm{H}_{2} \mathrm{O}_{2}$-treated HEK- 293 cells}

Morphological changes in HEK-293 cells are shown in Fig. 2A. Cells in the control group grew efficiently and maintained a typical growth pattern. However, cells in the model group obviously diminished in the number of viable cells. By contrast, cells pre-incubated with LFs for $1 \mathrm{~h}$ prior to $\mathrm{H}_{2} \mathrm{O}_{2}$ exposure, with higher number of viable cells, especially in the PL group. To further investigate the effects of $\mathrm{H}_{2} \mathrm{O}_{2}$ treatment on DNA and nuclear structure, we used DNA fluorescent dye 33258. Cells with intact DNA in the control group showed a uniformly stained nuclei, whereas cells with condensed chromatin and/or nuclei fragmentation in the $\mathrm{H}_{2} \mathrm{O}_{2}$-treated model group showed bright staining (Fig. 2B). However, cells pre-incubated with LFs showed mitigated morphological changes. Observed results 


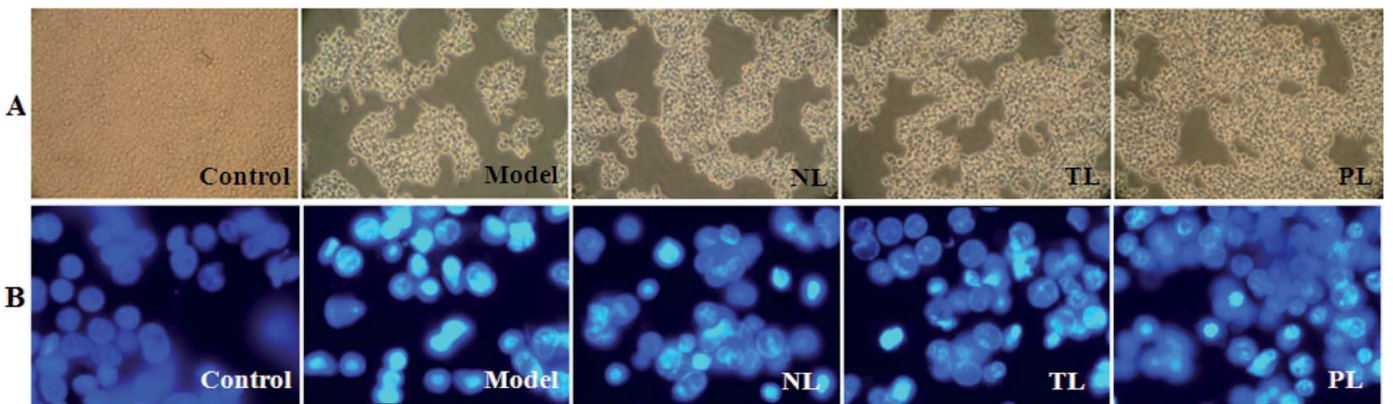

Fig. 2 Effects of silver-carp brain lipids on morphology of $\mathrm{H}_{2} \mathrm{O}_{2}$-injured HEK-293 cells. (A) Inverted-phase contrast microscope and (B) fluorescence microscopy. The model group was incubated with $1 \mathrm{mM} \mathrm{H}_{2} \mathrm{O}_{2}$ for $2 \mathrm{~h}$. Then, treatment groups were incubated with $1 \mathrm{mg} \mathrm{mL}^{-1}$ lipid fractions for $1 \mathrm{~h}$ prior to $\mathrm{H}_{2} \mathrm{O}_{2}$ addition. NL-neutral lipids, TL-total lipids, PL-polar lipids.

revealed that LFs protected HEK-293 cells against $\mathrm{H}_{2} \mathrm{O}_{2}$-induced oxidative damage, and influence of PLs was greater than that of NLs.

By phase-contrast microscopy, Kim et al. observed that DHA could efficiently prevent $\mathrm{H}_{2} \mathrm{O}_{2}$-induced oxidative cell death in primary astrocytes. ${ }^{19}$ Consistent with such results, we demonstrated that LFs, especially PLs, which are rich in DHA and other $\omega$-3 PUFAs, ${ }^{9}$ prevent $\mathrm{H}_{2} \mathrm{O}_{2}$-induced HEK-293 cell death and alleviate morphological changes. Nuclear condensation and DNA fragmentation are closely related to $\mathrm{H}_{2} \mathrm{O}_{2}$-induced cell death. ${ }^{20}$ Under nuclear fluorochrome staining, serious chromatin condensation or nuclear fragmentation, which was noted in the $\mathrm{H}_{2} \mathrm{O}_{2}$-treated HEK-293 cells, were observed to be similar to the work of Bian et al. ${ }^{15}$ However, LFs exerted protective effects against such changes.

\subsection{Effects of LFs on intracellular ROS levels of $\mathrm{H}_{2} \mathrm{O}_{2}$-treated HEK-293 cells}

Cells treated with $\mathrm{H}_{2} \mathrm{O}_{2}$ are known to enhance intracellular accumulation of ROS, whereas ROS can induce destruction of many biological molecules, such as DNA, proteins, lipids, and cell death. ${ }^{21,22}$ ROS in the model group was about 2.5 times higher than that of the control group (Fig. 3). However, ROS in

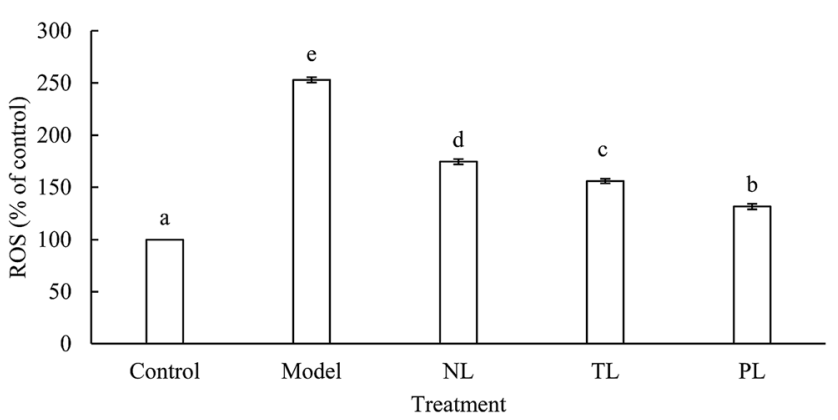

Fig. 3 Inhibition of silver-carp brain lipids on $\mathrm{H}_{2} \mathrm{O}_{2}$-induced $\mathrm{ROS}$ in HEK-293 cells. The model group was incubated with $1 \mathrm{mM} \mathrm{H}_{2} \mathrm{O}_{2}$ for $2 \mathrm{~h}$. Then, treatment groups were incubated with $1 \mathrm{mg} \mathrm{mL}^{-1}$ lipid fractions for $1 \mathrm{~h}$ prior to $\mathrm{H}_{2} \mathrm{O}_{2}$ addition. Results are reported as means $\pm \mathrm{SD}(n=3)$. The numbers followed by different letters are significantly different at $p<0.05$ on the basis of the Duncan test. NL-neutral lipids, TL-total lipids, PL-polar lipids. the NL, TL, and PL groups were about 1.7, 1.5, and 1.3 times, respectively, higher than that of the control group. Results clearly illustrate that LFs reduce ROS levels and protect cells against $\mathrm{H}_{2} \mathrm{O}_{2}$-induced oxidative damage.

Oxidative stress and ROS accumulation have been implicated in aging and many human chronic diseases. ${ }^{23}$ In a normal physiological process, mitochondria convert $1-2 \%$ of the consumed oxygen into ROS, whereas ROS levels dramatically increase under environmental stress, such as oxidative stress. ${ }^{24}$ Previous studies reported that $\omega-3$ PUFA treatment could significantly reduce ROS production. ${ }^{19}$ Fish oil is a well-known source of $\omega$-3 PUFAs. LFs from silver-carp brain have been proven to contain abundant $\omega-3$ PUFAs, ${ }^{9}$ indicating that LFs can diminish ROS content of $\mathrm{H}_{2} \mathrm{O}_{2}$-oxidative-damaged HEK-293 cells.

\subsection{Effects of LFs on lipid peroxidation and antioxidant enzyme activities of $\mathrm{H}_{2} \mathrm{O}_{2}$-treated HEK-293 cells}

Lipid peroxidation is one of the primary events in free radicalmediated cell injury. MDA is a by-product of lipid peroxidation induced by excessive ROS and is widely used as a biomarker of oxidative stress. ${ }^{25}$ HEK-293 cells treated with $1 \mathrm{mmol} \mathrm{L}{ }^{-1} \mathrm{H}_{2} \mathrm{O}_{2}$ for $2 \mathrm{~h}$ increased the intracellular MDA level by $241.46 \%$, whereas pre-incubation of cells with LFs attenuated the increase (Fig. 4A). In normal cell systems, a balance exists between generation of ROS and their elimination by cellular antioxidant systems, which are partly composed of some enzymes, such as SOD, GSH-Px, and CAT. Oxidative stress occurs when ROS generation is greater than the defense capacity of cellular antioxidant systems, or when normal antioxidant defense of cells is inhibited. Fig. 3 shows large amounts of ROS that were generated when HEK-293 cells were treated with $\mathrm{H}_{2} \mathrm{O}_{2}$. Meanwhile, activities of SOD, GSH-Px, and CAT dramatically decreased under $\mathrm{H}_{2} \mathrm{O}_{2}$ treatment (Fig. 4B-D), signifying the inhibition of antioxidant defense. However, preincubation with LFs significantly attenuated the decrease in enzyme activities, and treatment with PLs exerted the strongest protective effects against oxidative damage among the three LF groups (Fig. 4B-D). These findings suggest that LFs can inhibit $\mathrm{H}_{2} \mathrm{O}_{2}$-induced oxidative damage by protecting cellular antioxidant enzyme systems. 

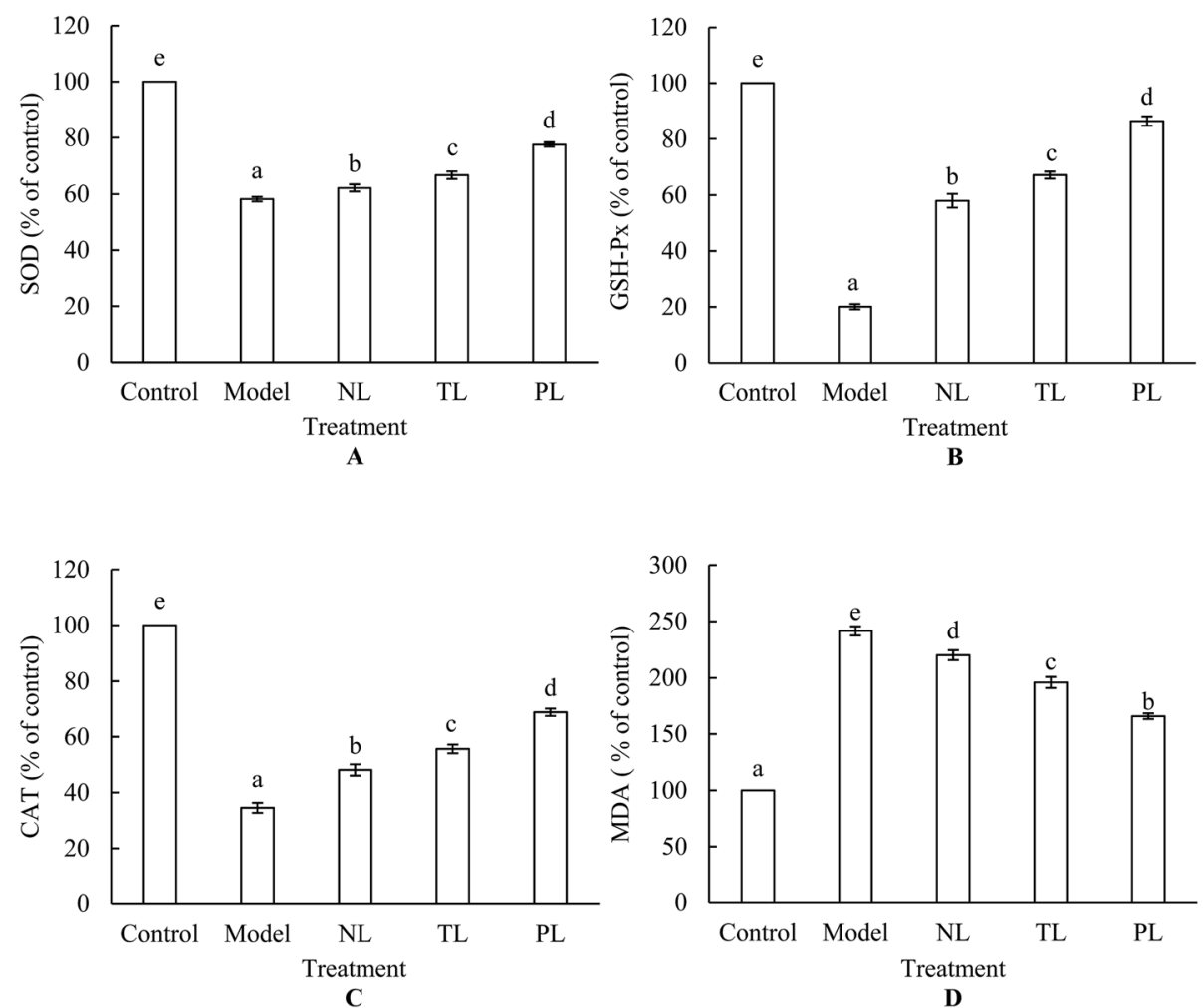

Fig. 4 Effects of silver-carp brain lipids on lipid peroxidation and antioxidant enzyme activities of $\mathrm{H}_{2} \mathrm{O}_{2}$-injured HEK-293 cells. (A) MDA; (B) SOD; (C) GSH-Px; (D) CAT. The model group was incubated with $1 \mathrm{mM} \mathrm{H}_{2} \mathrm{O}_{2}$ for $2 \mathrm{~h}$. Then, treatment groups were incubated with $1 \mathrm{mg} \mathrm{mL}^{-1}$ lipid fractions for $1 \mathrm{~h}$ prior to $\mathrm{H}_{2} \mathrm{O}_{2}$ addition. Results are reported as means $\pm \mathrm{SD}(n=3)$. The numbers followed by different letters are significantly different at $p<0.05$ on the basis of the Duncan test. NL-neutral lipids, TL-total lipids, PL-polar lipids.

Numerous reports have documented increases in antioxidant enzymes upon $\omega$-3 PUFA clinical treatment. ${ }^{26,27}$ Altinkilic et al. demonstrated the augmented GSH-Px activity of PC12 cells exposed to oxidative stress in response to fish-oil treatment. ${ }^{16}$ In this study, we demonstrated that LFs from silver-carp brain protected HEK-293 cells against $\mathrm{H}_{2} \mathrm{O}_{2}$-induced decrease in SOD, GSH-Px, and CAT activities. Aside from $\omega-3$ PUFA content, $\omega$ $6: \omega-3$ FA ratio is important. Chen et al. showed that diminishing $\omega-6: \omega-3$ FA ratio can enhance levels of cardiac antioxidant enzymes. ${ }^{28}$ Our previous studies demonstrated that the $\omega$ $6: \omega-3$ FA ratio of LFs derived from silver-carp brain follows a descending order: NLS > TLS > PLs, ${ }^{9,10}$ such trend may partly explain the strongest protection effects of PLs on antioxidant enzyme systems of HEK-293 cells.

\subsection{Effects of LFs on apoptosis of $\mathrm{H}_{2} \mathrm{O}_{2}$-treated HEK-293 cells}

Oxidative damage can cause DNA damage. ${ }^{29}$ Hence, we monitored the effects of LFs on DNA content of $\mathrm{H}_{2} \mathrm{O}_{2}$-damaged HEK293 cells. Compared with the control group, percentage of subG1 peak, a cell-apoptosis characteristic that indicates reduced DNA content, significantly elevated in $\mathrm{H}_{2} \mathrm{O}_{2}$-treated model group (18.88\%) (Fig. 5A). The percentages of sub-G1 peaks of the NL, TL, and PL groups are $12.36 \%, 6.08 \%$, and $1.83 \%$, respectively, suggesting the positive effects of LFs against $\mathrm{H}_{2} \mathrm{O}_{2}$ induced damage.
To further confirm that LFs may protect HEK-293 cells against oxidative damage, an annexin V-FITC/PI staining assay was performed (Fig. 4B). Most cells in the control group were scattered in the low left quadrant $\left(\mathrm{AV}^{-} / \mathrm{PI}^{-}\right)$. After $\mathrm{H}_{2} \mathrm{O}_{2}$ treatment, cells shifted to the low right quadrant $\left(\mathrm{AV}^{+} / \mathrm{PI}^{-}\right.$, indicating early apoptosis) and high right quadrant $\left(\mathrm{AV}^{+} / \mathrm{PI}^{+}\right.$, indicating late apoptosis or necrosis). However, pretreatment with LFs can decrease the $\mathrm{AV}^{+} / \mathrm{PI}^{-}$and $\mathrm{AV}^{+} / \mathrm{PI}^{+}$ cell populations. Thus, we conclude that LFs can protect $\mathrm{H}_{2} \mathrm{O}_{2}$-injured HEK-293 cells against the induction of apoptosis and necrosis. PLs exerted a stronger effect than TLs and NLs in inhibiting $\mathrm{H}_{2} \mathrm{O}_{2}$-induced apoptosis and necrosis.

The level of $\Delta \Psi_{\mathrm{m}}$, which represents mitochondrialmembrane integrity, is considered a critical indicator of apoptosis induced by the mitochondrial pathway. ${ }^{30}$ We monitored changes in $\Delta \Psi_{\mathrm{m}}$ by flow cytometry with JC-1. JC-1 exhibited potential-dependent accumulation in mitochondria, with the fluorescence of JC-1 dye shifting from red (FLH2) to green (FLH-1) upon loss of $\Delta \Psi_{\mathrm{m}}$. Compared with the control group, cells in the model group scattered below and to the right, showing decreased red fluorescence and increased green fluorescence (Fig. 5C). Therefore, red-to-greenfluorescence ratio decreased from 4.17 (control group) to 1.31 (model group) and reflects the collapse of mitochondrial integrity. However, compared with the model group, cells were 

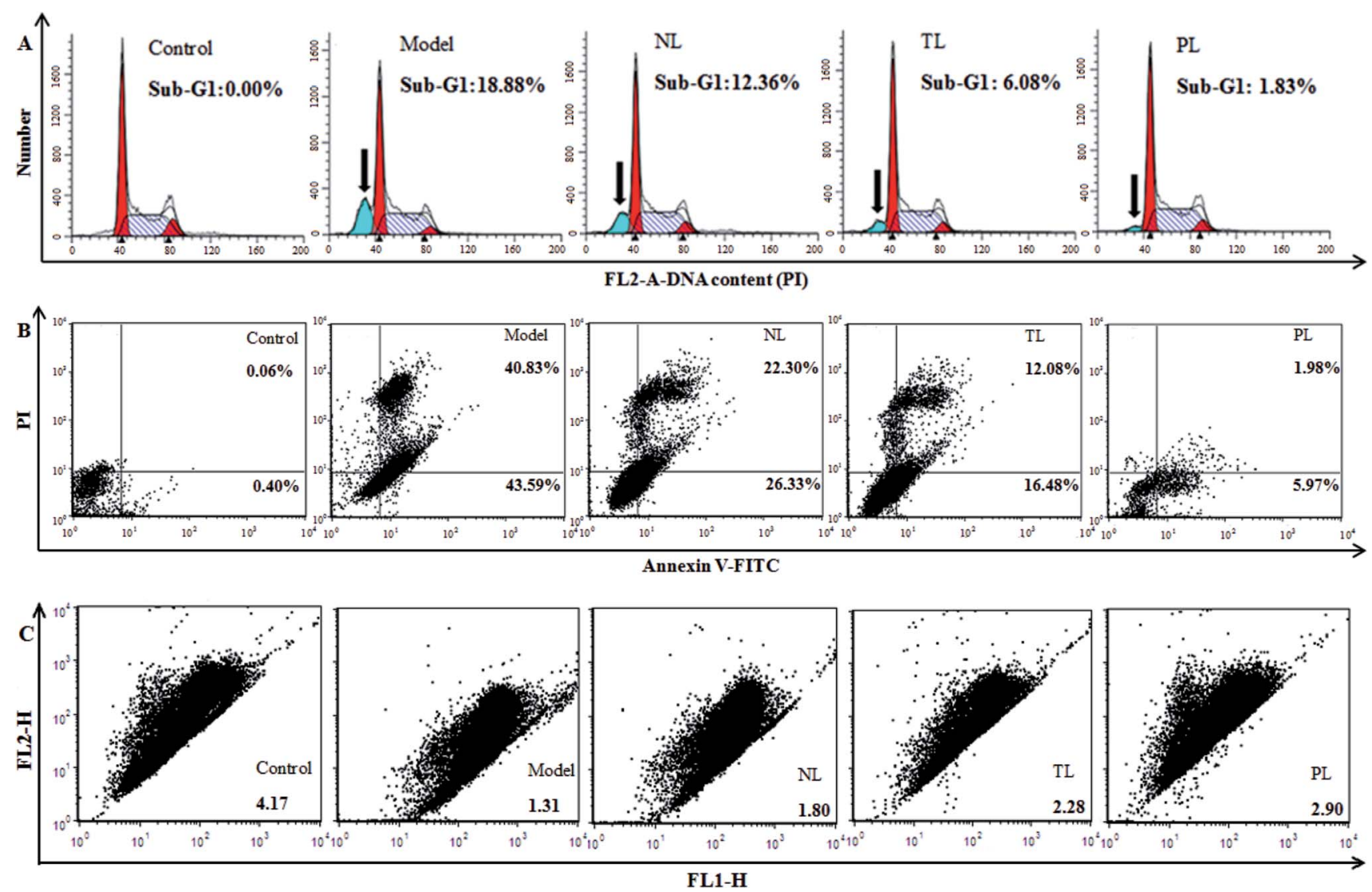

Fig. 5 Protective effects of silver-carp brain lipids against $\mathrm{H}_{2} \mathrm{O}_{2}$-induced apoptosis in $\mathrm{HEK}-293$ cells. (A) DNA content. Sub-G1 peak, which indicates reduced DNA content, was used to demonstrate cell apoptosis. (B) Apoptosis. Early apoptotic cells are annexin $V$-FITC positive and PI negative $\left(\mathrm{AV}^{+} / \mathrm{PI}^{-}\right)$, and late apoptotic or dead cells are positive to both annexin $\mathrm{V}$-FITC and $\mathrm{PI}\left(\mathrm{AV}^{+} / \mathrm{PI}^{+}\right)$. (C) $\Delta \Psi_{\mathrm{m}}$. Ratio of red-to-green arithmetic mean (FL2-H and FL1-H) was used to demonstrate cell damage. The model group was incubated with $1 \mathrm{mM} \mathrm{H}_{2} \mathrm{O}_{2}$ for $2 \mathrm{~h}$. Then, treatment groups were incubated with $1 \mathrm{mg} \mathrm{mL}^{-1}$ lipid fractions for $1 \mathrm{~h}$ prior to $\mathrm{H}_{2} \mathrm{O}_{2}$ addition. NL-neutral lipids, TL-total lipids, PL-polar lipids.

pre-incubated with LFs showed increased ratios of $1.80,2.28$, and 2.90 for NL, TL, and PL groups, respectively. LFs inhibited the decrease in $\Delta \Psi_{\mathrm{m}}$ caused by $\mathrm{H}_{2} \mathrm{O}_{2}$ and therefore prevented HEK-293 cells from incurring oxidative damage. PLs showed the weakest effect in eliciting depolarization of $\Delta \Psi_{\mathrm{m}}$ in the three LF groups.

Oxidative damage is closely related to cardiovascular, liver, cancer, inflammatory and other chronic diseases. ${ }^{31}$ Clinical studies showed that fish-oil intake could enhance antioxidant capacity, ${ }^{32,33}$ and protect the body against atherosclerotic heart disease, myocardial infarction, and sudden death. ${ }^{34}$ Fish oil contains sufficient amount of $\omega-3$ PUFAs. Evidence from previous studies showed that $\omega-3$ PUFAs, especially DHA and EPA, could inhibit oxidative stress-induced apoptosis. ${ }^{35,36}$ Liu et al. studied the effects of $\omega-3$ PUFAs on $\mathrm{H}_{2} \mathrm{O}_{2}$-induced oxidative mouse NPCs. The researchers observed that DHA treatment could significantly decrease the number of apoptotic cells. ${ }^{17}$ ROS induced $\Delta \Psi_{\mathrm{m}}$ cell collapse, and $\Delta \Psi_{\mathrm{m}}$ loss is a hallmark event of apoptosis. Fish oil attenuates mitochondrial dysfunctions $^{37}$ and DHA enhances $\Delta \Psi_{\mathrm{m}} \cdot{ }^{38}$ Results of our studies were consistent with these findings, displaying that LF treatment resisted $\mathrm{H}_{2} \mathrm{O}_{2}$-induced increases in ROS, apoptotic and necrotic levels, and $\mathrm{H}_{2} \mathrm{O}_{2}$-induced decrease in $\Delta \Psi_{\mathrm{m}}$ of HEK-293 cells
(Fig. 3 and 5). Different protective effects of TLs, NLs, and PLs can be ascribed to their different FA profiles.

Fish lipids rich in $\omega-3$ PUFAs are susceptible to oxidation because of their high degree of unsaturation, and this phenomenon may partly explain their protective effects on attenuating $\mathrm{H}_{2} \mathrm{O}_{2}$-induced oxidative damage to cells. In addition, PUFAs are essential components of membrane phospholipids and have a specific influence on membrane properties. Studies have demonstrated that supplemented $\omega-3$ PUFAs rapidly incorporate into cell phospholipid membranes and modify membrane biophysical characteristics and functions. ${ }^{39}$ Membranes enriched in $\omega-3$ PUFAs show increased membrane fluidity. ${ }^{17}$ Increases in membrane fluidity may be responsible for some of the protective effects of the fish lipids. Other potential mechanisms may relate to the inhibition of the prooxidant enzyme phospholipase $A_{2}$. Phospholipase $A_{2}$ plays important role in eicosanoids biosynthesis, ${ }^{40}$ which may involve some unwanted actions, such as inflammatory response. In addition, further mechanisms of how fish lipids and their metabolites are involved in the protective effects against oxidative damage need further study. A study of the antioxidant activities of lipids from silver carp brain may provide valuable insights into the role of fish lipids in boosting health. 


\section{Conclusion}

In conclusion, LFs from silver-carp brain resist $\mathrm{H}_{2} \mathrm{O}_{2}$-induced oxidative injury in HEK-293 cells by reducing cellular ROS levels, protecting cellular antioxidant enzyme systems, inhibiting cell apoptosis and necrosis, and attenuating mitochondrial dysfunctions. Upon comparison of protective functions of LFs, PLs were observed to be the most effective. These findings may assist in explaining the protective effects of fish lipids against diseases caused by oxidative damage and provide possibilities for potential use of lipids from silver-carp brain in health improvement.

\section{Acknowledgements}

This study was supported by the earmarked fund for China Agriculture Research System (CARS-46) and Wujiang Changyang Fishery Ecological Technology Development Corporation.

\section{References}

1 P. M. Kris-Etherton, W. S. Harris, L. J. Appel and C. Nutrition, Circulation, 2002, 106, 2747-2757.

2 L. G. Cleland, G. E. Caughey, M. J. James and S. M. Proudman, J. Rheumatol., 2006, 33, 1973-1979.

3 A. M. Hill, J. D. Buckley, K. J. Murphy and P. R. C. Howe, Am. J. Clin. Nutr., 2007, 85, 1267-1274.

4 T. Heitzer, T. Schlinzig, K. Krohn, T. Meinertz and T. Munzel, Circulation, 2001, 104, 2673-2678.

5 D. Richard, K. Kefi, U. Barbe, P. Bausero and F. Visioli, Pharmacol. Res., 2008, 57, 451-455.

6 T. A. Mori, Redox Rep., 2004, 9, 193-197.

7 K. Reppond, A. C. M. De Oliveira and P. J. Bechtel, J. Aquat. Food Prod. Technol., 2009, 18, 209-222.

8 I. S. Stoknes, H. M. W. Okland, E. Falch and M. Synnes, Comp. Biochem. Physiol., Part B: Biochem. Mol. Biol., 2004, 138, 183-191.

9 C. X. Wang, W. S. Xia, Y. S. Xu, Q. X. Jang and P. P. Yu, J. Am. Oil Chem. Soc., 2013, 90, 1301-1309.

10 C. X. Wang, W. S. Xia, Y. S. Xu, Q. X. Jang and P. P. Yu, J. Am. Oil Chem. Soc., 2014, 91, 1471-1476.

11 C. X. Wang, W. S. Xia, Q. X. Jang, Y. S. Xu and P. P. Yu, Food Funct., 2014, 5, 2194-2201.

12 C. X. Wang, W. S. Xia, Y. S. Xu, Q. X. Jiang, S. S. Yin, Y. W. Yang and P. P. Yu, Lipids Health Dis., 2013, 12, DOI: 10.1186/1476-511X-12-94.

13 J. Folch, M. Lees and G. H. Sloane Stanley, J. Boil. Chem., 1957, 226, 497-509.

14 D. S. Galanos and V. M. Kapoulas, J. Lipid Res., 1962, 1-3, 134-137.

15 Y. Y. Bian, J. Guo, K. X. Zhu, X. N. Guo, W. Peng and H. M. Zhou, RSC Adv., 2015, 5, 16116-16124.
16 S. Altinkilic, M. Naziroglu, A. C. Uguz and R. Ozcankaya, J. Membr. Biol., 2010, 235, 211-218.

17 Q. Liu, D. Wu, N. Ni, H. Ren, C. Luo, C. He, J. X. Kang, J. B. Wan and H. Su, Mar. Drugs, 2014, 12, 2341-2356.

18 E. Boselli, D. Pacetti, P. Lucci and N. G. Frega, J. Agric. Food Chem., 2012, 60, 3234-3245.

19 E. J. Kim, Y. G. Park, E. J. Baik, S. J. Jung, R. Won, T. S. Nahm and B. H. Lee, J. Neurosci. Res., 2005, 79, 670-679.

20 J. H. Jang and Y. J. Surh, Mutat. Res., Genet. Toxicol. Environ. Mutagen., 2001, 496, 181-190.

21 Y. J. Zhou, S. P. Zhang, C. W. Liu and Y. Q. Cai, Toxicol. in Vitro, 2009, 23, 288-294.

22 M. D. Temple, G. G. Perrone and I. W. Dawes, Trends Cell Biol., 2005, 15, 319-326.

23 K. C. Kregel and H. J. Zhang, Am. J. Physiol.: Regul., Integr. Comp. Physiol., 2007, 292, R18-R36.

24 C. B. Liu, J. Hong, H. L. Yang, J. Wu, D. Y. Ma, D. S. Li, D. H. Lin and R. Lai, Free Radicals Biol. Med., 2010, 48, 1173-1181.

25 X. Y. Lu, H. Guo and Y. L. Zhang, Int. J. Biol. Macromol., 2012, 50, 50-58.

26 R. De Caterina, N. Engl. J. Med., 2011, 364, 2439-2450.

27 D. Mozaffarian and J. H. Y. Wu, J. Am. Coll. Cardiol., 2011, 58, 2047-2067.

28 W. Chen, J. P. Wang and Y. Q. Huang, Livest. Sci., 2012, 150, 114-120.

29 K. X. Zhu, X. Guo, X. N. Guo, W. Peng and H. M. Zhou, Food Res. Int., 2013, 53, 297-303.

30 H. C. Wang, J. H. Yang, S. C. Hsieh and L. Y. Sheen, J. Agric. Food Chem., 2010, 58, 7096-7103.

31 H. C. Ting, Y. W. Hsu, C. F. Tsai, F. J. Lu, M. C. Chou and W. K. Chen, Food Chem., 2011, 125, 652-659.

32 A. Jahangiri, W. R. Leifert, K. L. Kind and E. J. McMurchie, Free Radical Biol. Med., 2006, 40, 1592-1602.

33 X. Capo, M. Martorell, A. Sureda, I. Llompart, J. A. Tur and A. Pons, Eur. J. Nutr., 2015, 54, 35-49.

34 T. A. Mori and L. J. Beilin, Curr. Opin. Lipidol., 2001, 12, 1117.

35 R. Asmis and E. S. Wintergerst, Eur. J. Biochem., 1998, 255, 147-155.

36 D. Wang, L. Y. Zhang, M. Wen, L. Du, X. Gao, C. H. Xue, J. Xu and Y. M. Wang, J. Funct. Foods, 2016, 25, 385-396.

37 K. M. D. Joseph and M. Muralidhara, Food Chem. Toxicol., 2012, 50, 1529-1537.

38 Y. Ng, R. Barhoumi, R. B. Tjalkens, Y. Y. Fan, S. Kolar, N. Y. Wang, J. R. Lupton and R. S. Chapkin, Carcinogenesis, 2005, 26, 1914-1921.

39 E. R. Brown and P. V. Subbaiah, Lipids, 1994, 29, 825-829.

40 E. A. Dennis, Am. J. Respir. Crit. Care Med., 2000, 161, S32S35. 